\title{
RESEARCH PAPER \\ The inclusion of distiller's dried corn grains with solubles in the feed of laying hens during the production stage
}

\author{
Hernán E. Rodríguez-Ríos ${ }^{1}$, Jorge A. Campos-Parraํㄹ, Pamela A. Williams- \\ Salinas ${ }^{1}$, Markus H. Blanck-Heimann¹, Rita G. Astudillo-Neira ${ }^{1}$, and Jesús \\ D. Grande-Cano ${ }^{2}$
}

${ }^{1}$ Departamento de Producción Animal, Facultad de Agronomía, Universidad de Concepción, Ave. Vicente Mendez 595, Chillán, Chile.

${ }^{2}$ Área de Sistemas de Producción Agropecuarios. División de Ciencias Biológicas y de la Salud. Universidad Autónoma Metropolitana Iztapalapa. CP 09340 Mexico D.F., Mexico.

\begin{abstract}
H.E. Rodríguez-Ríos, J.A. Campos-Parra, P.A. Williams-Salinas, M.H. Blanck-Heimann, R.G. Astudillo-Neira, and J.D. Grande-Cano. 2015. The inclusion of distiller's dried corn grains with solubles in the feed of laying hens during the production stage. Cien. Inv. Agr. 42(3): 331-339. The aim of this study was to assess the effects of distiller's dried corn grains with solubles (DDGS) in the diet of laying hens on their productive parameters (live weight, laying percentage, and feed intake) and egg quality (egg weight, mass, yolk color and shell thickness). This study was conducted in the Andes Mountains in Parral, Chile. It covered a span of 13 weeks of productive egg laying, ranging from the 31st to the 44th week of life of the hens. The experimental design was a random complete block using 225 Hy-Line Brown breed hens, distributed in 5 treatments, where each treatment consisted of three repetitions in 15 hens. The treatments included replacing soybean concentrate with DDGS at levels that corresponded to inclusion in the diet of 5, 10, 15 and 20\%. The laying percentage, feed intake and feed conversion did not decrease with increasing levels of DDGS in the diet, but there was a slight decrease in egg weight and a lower egg mass. Yolk color increased with increasing levels of DDGS. The use of DDGS is possible as a replacement for soybean bran in levels up to $20 \%$ in the diet of laying hens without affecting their production, as demonstrated by the lack of significant differences among treatments in measured egg laying parameters.
\end{abstract}

Key words: Egg production, Hy-Line Brown, soybean bran.

\section{Introduction}

In Chile, both corn and soybean concentrate are the most common products in the diets of laying hens (Fundación Chile, 2007; ODEPA, 2010).

Received April 20, 2015. Accepted November 18, 2015. Corresponding author: herodrig@udec.cl
Distiller's dried corn grains with solubles (DDGS) are considered a by-product of the bioethanol elaboration process, and they are formed in the same proportion as the other resulting products, ethanol and $\mathrm{CO}_{2}$. Thus, they correspond to about one third of the final products (Roberson et al., 2005). 
The availability of DDGS is incrementally increasing as a result of the production of bioethanol. In 2008, the USA had a total production of 12 million tons (Gibson and Karges, 2006), whereas in 2011 the production was 52 million tons (De Camargo Bini, et. al., 2012). In Chile, there have been emerging studies of the installation of biodiesel plants from agriculture products (Muñoz-Lagos et al., 2010). Therefore, the possibility of the efficient use of DDGS in animal production, especially in the diets of poultry and swine, is increasing.

The nutritional composition of DDGS suggests that its concentration of proteins fluctuates between 23 and 30\% (Batal and Dale, 2006). However, the protein values are lower in maize $(8.84 \%)$ and below that registered for soybean concentrate (47\%) (Cuca et al., 2003). The metabolizable energy in DDGS varies between 2490 and 3190 $\mathrm{kcal} \mathrm{kg}^{-1}$ on a dry matter basis (Batal and Dale, 2006; Waldroup et al., 2007).

According to Roberson et al. (2005), the incorporation of $15 \%$ DDGS into the diet of laying hens does not affect egg production, and additional synthetic lysine is not needed.

There has been a lack of studies in our country regarding the use of DDGS in the commercial feed of laying hens. The aim of the current study was to assess the effect of the inclusion of DDGS as a replacement for soybean bran in relation to productive parameters and egg quality in laying hens.

\section{Material and Methods}

The study was conducted in a poultry farm located in Villa Baviera, Municipality of Parral, Chile ( $36^{\circ} 09^{\prime} 00^{\prime \prime} \mathrm{S}$ and $\left.71^{\circ} 50^{\prime} 00^{\prime \prime} \mathrm{W}\right)$. It lasted 13 weeks, from the 31st to the 44th weeks of life of the hens. A total of 225 Hy-Line Brown breed laying hens were used, aged 31 weeks of age at the beginning of the study, with an initial weight of $2011 \pm 54.46 \mathrm{~g}$. Hens were part of a stable of 3,200 hens inside a barn $27 \mathrm{~m}$ long, $7 \mathrm{~m}$ wide and $5 \mathrm{~m}$ high. Natural ventilation was produced by side openings in both upper and lower sectors of the wall. Hens were confined in cages divided in three sections each with a capacity of 5 hens per section, housed on three floors.

Artificial illumination 18 Watt light bulbs were placed over the longitudinal corridors separated $6 \mathrm{~m}$ each. Artificial illumination was controlled by an automatic clock. The illumination regimen used included an average of $17 \mathrm{~h}$ light per day, both natural and artificial light. A proximate analysis of the used DDGS is shown in Table 1. The diet for laying hens was formulated (Table 2) in order to satisfy their nutritional requirements, modifying the remaining ingredients to preserve isocaloric and isoproteic diets (Table 3). Drinking water was available ad libitum during the study. In order to provide water, nipple drinkers were located convenient to the hens. Feed was offered once a day. Treatments were formulated using increasing levels of DDGS in replacement of soybean concentrate, corresponding to inclusion levels in the diet of $0,5,10,15$ and $20 \%$ on a dry weight basis (Table 2). Diets were subjected to proximal chemical analysis, according to standardized analytical protocols (Cunniff, 1996). The experimental design was randomized by complete blocks, with 5 treatments of 3 repetitions of 15 birds each. During the study, the following measurements were performed: a) The live weight of the hens ( $g$ bird $^{-1}$ ) was measured. All hens were weighed on a

Table 1. Proximal analysis of DDGS used in diets.

\begin{tabular}{lc}
\hline Nutrients & Dry-matter basis, ${\mathrm{g} 100 \mathrm{~g}^{-1}}^{-100.00}$ \\
\hline Dry matter & 4.84 \\
Ash & 24.56 \\
Crude protein & 13.52 \\
Ether extract & 5.66 \\
Crude fiber & 51.42 \\
Nitrogen free extracts & $3,987 \mathrm{kcal} \mathrm{kg}^{-1}$ \\
\hline
\end{tabular}




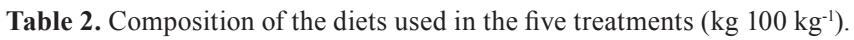

\begin{tabular}{lccccc}
\hline & \multicolumn{5}{c}{ Treatments (\%) } \\
\cline { 2 - 5 } Ingredients & 0 & 5 & 10 & 15 & 20 \\
\hline Corn grain & 64.00 & 60.70 & 57.50 & 54.20 & 51.00 \\
Wheat bran & 1.70 & 3.20 & 4.60 & 6.10 & 7.50 \\
Soybean concentrate & 16.00 & 12.00 & 8.00 & 4.00 & 0.00 \\
Corn DDGS & 0.00 & 5.00 & 10.00 & 15.00 & 20.00 \\
Fish meal & 6.00 & 7.00 & 8.00 & 9.00 & 10.00 \\
Calcium bicarbonate $\left(\mathrm{Ca} \mathrm{CO}_{3}\right)$ & 11.00 & 11.00 & 11.00 & 11.00 & 11.00 \\
Common salt (Na Cl) & 0.20 & 0.20 & 0.20 & 0.20 & 0.20 \\
Bicalcium phosphate & 0.80 & 0.60 & 0.40 & 0.20 & 0.00 \\
Vitamin mixture & 0.10 & 0.10 & 0.10 & 0.10 & 0.10 \\
Mineral mixture & 0.10 & 0.10 & 0.10 & 0.10 & 0.10 \\
D. L. Methionine & 0.10 & 0.10 & 0.10 & 0.10 & 0.10 \\
Lysine amino acid & 0.01 & 0.01 & 0.01 & 0.01 & 0.01 \\
\hline
\end{tabular}

Vitamin mixture: consisted of vitamins A, D, E, K, B2, B12, nicotinic acid, calcium pantothenate, folic acid, biotin, choline chloride and antioxidants.

Minerals: mixture consisted of $\mathrm{Cu}, \mathrm{Fe}, \mathrm{Zn}, \mathrm{Mn}$ and $\mathrm{Co}$.

Table 3. Nutrients supplied by diets v/s requirements (Hy-Line International, 2005), according to the inclusion levels of corn DDGS.

\begin{tabular}{|c|c|c|c|c|c|c|}
\hline \multirow[b]{2}{*}{ Nutrients } & \multicolumn{5}{|c|}{ Treatments $(\%)$} & \multirow[b]{2}{*}{ Requirements } \\
\hline & 0 & 5 & 10 & 15 & 20 & \\
\hline Crude protein (\%) & 16.40 & 16.30 & 16.30 & 16.30 & 16.30 & 16.30 \\
\hline Metabolizable energy $\left(\mathrm{kcal} \mathrm{kg}^{-1}\right)$ & 2,716 & 2,719 & 2,723 & 2,726 & 2,729 & 2,700 \\
\hline Lysine (\%) & 0.93 & 0.91 & 0.89 & 0.87 & 0.85 & 0.85 \\
\hline Methionine+Cysteine (\%) & 0.70 & 0.72 & 0.74 & 0.76 & 0.79 & 0.65 \\
\hline Calcium (\%) & 4.07 & 4.06 & 4.04 & 4.03 & 4.01 & 4.00 \\
\hline Phosphorous (\%) & 0.38 & 0.40 & 0.42 & 0.43 & 0.45 & 0.34 \\
\hline
\end{tabular}

Soehnle electronic scale at the initiation and the end of the experimental period; b) Weekly average egg-laying was measured on the basis of the hen-day method; c) Weekly average feed intake was measured once a week before feeding the hens, and the residual feed was collected from feeders. The actual intake of the hens per week was obtained from the difference (feed offered - feed collected) (number birds ${ }^{-1}$ ); d) Weekly feed conversion was measured; the consumed feed in $\mathrm{kg}$ was quantified, and it was divided by dozens of eggs produced; and d) Mortality was determined by calculating the number of dead hens divided by the total of number of hens in the treatment, and it was expressed in percentage. In addition, in a sample of 10 eggs randomly obtained weekly per treatment the following aspects were measured: a) average weight (g), weighed on an Osenle electronic scale with $1 \mathrm{~g}$ sensitivity; b) Egg mass, which corresponded to the egg weight per laying percentage divided by 100 ; c) Yolk color, determined by the HoffmanLa Roche (1-15) colorimetric scale; and d) Egg shell thickness, determined using the method by Olsson (1936).

Results obtained in the study were subjected to a variance analysis using the contrast test proposed by Duncan (1974). Assumptions from the variance analysis were verified by means of the Shapiro Wilks test, modified for normality, and Bartlett's test for the homogeneity of the 
variance. Variables that did not fulfill the assumptions of the model were transformed by means of the function $\sqrt{x+0.5}$. For the yolk color variable, the Kruskal-Wallis non-parametric variance analysis test and the contrast test proposed by Conover (1999) were used. Statistical analyses were performed using the Infostat statistical software (Balzarini et al., 2008), with 95\% confidence.

\section{Results and Discussion}

\section{Hens'live weight}

Hens' live weight at the beginning of assessment varied between 1957 and $2057 \mathrm{~g}$ per hen and at the end between 1886 and $1970 \mathrm{~g}$ per hen. In all treatments, a lowering in body weight was observed (Table 4). Nevertheless, at the beginning and end of the experimental period, the average weight of the hens was found to be above the range recommended for the Hy-Line Brown breed at this age $(1910-1950 \mathrm{~g})$. Low weight was due to the increase in the room temperature during the assessment period (Figure 1), which generated lower feed intake. This is in agreement with results obtained by Castello et al. (1989) and Leeson et al. (2000).

\section{Egg-laying}

Egg-laying percentage fluctuated between 88.6 and $93.1 \%$ when using DDGS as a diet

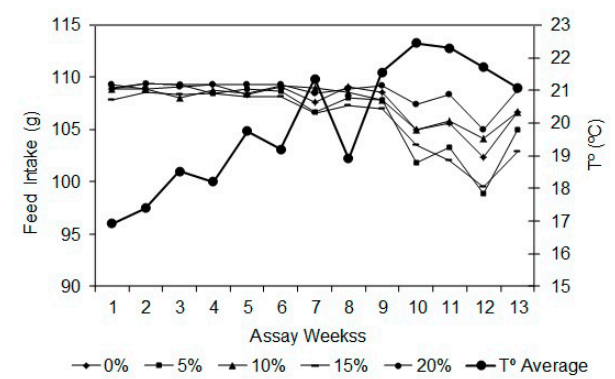

Figure 1. Feed intake (g bird-1 day-1) during the study with respect to the inclusion levels of corn DDGS v/s weekly temperature $\left({ }^{\circ} \mathrm{C}\right)$. ingredient, replacing soybean concentrate, without statistically significant differences among treatments $(\mathrm{p}>0.05)$. The highest laying percentage $(93.1 \%)$ was obtained in birds in the control treatment, and the lowest laying percentage (88.6\%) was obtained in hens with $15 \%$ inclusion (Table 5).

In Table 5, it can be observed that the production of eggs tended to decrease as the inclusion percentage of DDGS increased. However, the reduction did not occur uniformly because hens from treatments with $10 \%$ and $20 \%$ inclusion showed higher values of egg-laying percentages than those of $5 \%$ and $15 \%$, respectively.

Treatment with an inclusion of $10 \%$ DDGS with an egg-laying percentage of $91.2 \%$ was highlighted among other treatments, although it was only 1.9 percentage points lower than the control and was not statistically significantly different from the other groups ( $>00.05)$. Roberson et al. (2005) and Lumpkins et al. (2005) observed a negative trend in egg production with increasing levels of DDGS in the diets of laying hens, but production was not significantly affected ( $p>0.05$ ) by using up to $15 \%$ of this product in the total diet. However, in this study differences in egg-laying were observed $(\mathrm{p}>0.05)$ until a level of $20 \%$ DDGS. This trend towards a decrease in production could be explained because the quality of protein from DDGS is lower than that of soybean, and the contents of the amino acids are relatively deficient, especially in the case of the lysine (Lumpkins et al., 2005).

According to Elwinger (2007), in the USA, no more than $10 \%$ DDGS is recommended in poultry diets. This recommendation would not be appropriate in terms of productivity because the outcomes from the present study indicate that with some variations, production would tend to be stable over time.

By analyzing the egg-laying percentage in the evaluation period, a production decrease across 
Table 4. Live weight variation of birds with respect to inclusion levels of corn DDGS.

\begin{tabular}{lccccc}
\hline & \multicolumn{5}{c}{ Treatments (\%) } \\
\cline { 2 - 6 } Parameters & 0 & 5 & 10 & 15 & 20 \\
\hline Initial weight $\left(\mathrm{g} \mathrm{bird}^{-1}\right)$ & 2,029 & 2,047 & 2,057 & 1,957 & 1,967 \\
Final weight $\left(\mathrm{g} \mathrm{bird}^{-1}\right)$ & 1,963 & 1,970 & 1,946 & 1,866 & 1,885 \\
Weight variation $(\mathrm{g})$ & -66 & -78 & -111 & -90 & -82 \\
\hline
\end{tabular}

CV: coefficient variation.

Table 5. Productive parameters and egg quality in laying hens, according to the inclusion levels of corn DDGS.

\begin{tabular}{lccccccc}
\hline \multirow{2}{*}{ Treatments (\%) } & \multicolumn{4}{c}{ Productive Parameters } & \multicolumn{4}{c}{ Egg Quality Parameters } \\
\cline { 2 - 8 } & Egg-laying \% & FI g hen $^{-1}$ day $^{-1}$ & FC kg dozen eggs $^{-1}$ & S.T. mm & EW g & EM g hen $^{-1}$ day $^{-1}$ & YC \\
\hline 0 & 93.1 & $106.7 \mathrm{bc}^{1}$ & $1.39 \mathrm{a}$ & 0.33 & $65.0 \mathrm{bc}$ & $60.57 \mathrm{~b}$ & $10.4 \mathrm{a}$ \\
5 & 91.2 & $105.0 \mathrm{ab}$ & $1.41 \mathrm{ab}$ & 0.34 & $64.1 \mathrm{abc}$ & $58.00 \mathrm{a}$ & $10.5 \mathrm{~b}$ \\
10 & 92.5 & $106.7 \mathrm{bc}$ & $1.43 \mathrm{ab}$ & 0.33 & $62.8 \mathrm{ab}$ & $57.72 \mathrm{a}$ & $10.6 \mathrm{bc}$ \\
15 & 88.6 & $102.8 \mathrm{a}$ & $1.44 \mathrm{ab}$ & 0.34 & $65.2 \mathrm{c}$ & $57.76 \mathrm{a}$ & $10.7 \mathrm{c}$ \\
20 & 89.3 & $108.8 \mathrm{c}$ & $1.46 \mathrm{~b}$ & 0.33 & $63.0 \mathrm{a}$ & $56.34 \mathrm{a}$ & $10.8 \mathrm{~d}$ \\
CV\% & 2.52 & 0.65 & 2.31 & 1.47 & 1.50 & 1.85 & \\
Significant $^{2}$ & $\mathrm{Ns}$ & $\mathrm{s}$ & $\mathrm{s}$ & $\mathrm{s}$ & $\mathrm{s}$ & $\mathrm{s}$ & $\mathrm{s}$ \\
\hline
\end{tabular}

${ }^{1}$ Differences (by letter) in columns for egg laying, feed intake, feed conversion, shell thickness, egg weight, egg mass and yolk color were statistically significant, according to Duncan and yolk color to Conover $(\mathrm{p} \leq 0.05)$.

${ }^{2}$ Significant. ns: not significant. s: significant.

Egg-laying (\%). FI: Feed Intake (g (hens day) $\left.{ }^{-1}\right)$. FC: Feed Conversion (kg (dozen eggs) $\left.)^{-1}\right)$. ST: Shell Thickness (mm). EW: Egg Weight (g). EM: Egg Mass (g hens day) $\left.{ }^{-1}\right)$. YC: Yolk Color.

CV: coefficient variation

all treatments was observed without significant statistical differences ( $p>0.05)$ (Figure 2). This could be due to the hens aging (Castello et al., 1989), to lower feed intake, or it could be a product of an increase in the room temperature (Calvert, 1978). This phenomenon also appeared in the study of Roberson et al. (2005). Therefore, this variation was not attributed to the change of the diet because the decrease in the production was similar across all treatments, including the control treatment. When the temperature decreases, the egg-laying percentage tends to decrease because of decreasing feed intake. This also causes a decrease in the protein ingestion which, in turn, results not only in lower production but also in a notorious decrease in the weight of the eggs (Calvert, 1978), all of which are aspects considered in this study. Maximum egg-laying percentage is usually achieved in the range of 18 to $21^{\circ} \mathrm{C}$. Production is worsened both above and under these levels (Calvert, 1978).

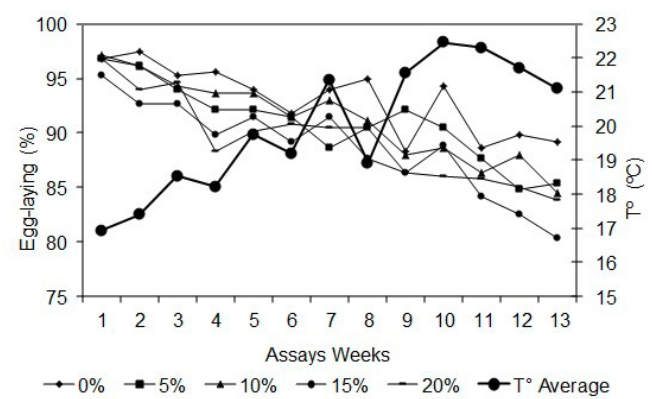

Figure 2. Variations in egg production (\% egg-laying) during the study with respect to the inclusion levels of corn DDGS v/s weekly average temperature $\left({ }^{\circ} \mathrm{C}\right)$.

\section{Feed intake}

In Table 5, the effects on intake were observed by incorporating increasing doses of DDGS in replacement of the soybean concentrate in the diet of laying hens. Among controls and treatment groups with an inclusion of 5, 10 and $20 \%$, no 
statistically significant differences were observed ( $p>0.05$ ), but the birds from the treatment group with $15 \%$ inclusion presented with lower intake with respect to the others, reaching only 102.8 $\mathrm{g}$ (bird day $)^{-1}$. This treatment differentiated ( $\mathrm{p} \leq 0.05$ ) from treatment groups 0,10 and $20 \%$, but was not significantly different $(\mathrm{p} \leq 0.05)$ from the birds treated with $5 \%$ inclusion. It is interesting to note that birds from the treatment group with $20 \%$ DDGS in their diets presented with greater intake and were differentiated $(\mathrm{p} \leq 0.05)$ from the birds treated with 5 and $15 \%$ inclusion. These results showed a clear trend in the feed intake with increasing levels of DDGS in the diet. This could be due to the temperatures present during the period of assessment (Figure 1). Roberson et al. (2005) observed a slight decrease in feed intake by including 5, 10 and 15\% DDGS, whereas Lumpkins et al. (2005) indicated the feed intake tends to increase by including $15 \%$ corn DDGS in the diet of laying hens, without observable differences $(p>0.05)$. Feed intake averages during the whole period were lower than the standards for laying hens from the Hy-Line Brown breed, from 31 to 44 weeks of age (Hy-Line International, 2005). These differences could be because the assessment was carried out from November 2008 to January 2009 , in which maximum temperatures reached $32{ }^{\circ} \mathrm{C}$. This may be why from the ninth week, there was a notable decrease in feed intake (Figure 1). According to Hy-Line International (2005), room temperature must be within the range of 18 to $27^{\circ} \mathrm{C}$. According to Castello et al. (1989), feed intake should not be lower than between 6 and $9 \mathrm{~g}$ as a result of an increase in the room temperature of $5{ }^{\circ} \mathrm{C}$. Castello et al. (1989) asserts that the reductions in feed intake due to an increase in room temperature vary by approximately $1.5 \%$ per $1{ }^{\circ} \mathrm{C}$ under moderate temperatures $\left(18 \pm 4{ }^{\circ} \mathrm{C}\right)$. This allows for the deduction that the decrease in feed intake during the study did not occur as a result of the inclusion of DDGS in the diet but as a result of an increase in the room temperature.

\section{Feed conversion}

There was a variation from 1.39 to $1.46 \mathrm{~kg}$ of consumed feed per dozen eggs produced and a slight increase as the percentage of DDGS was incremented in diet, without statistically significant differences ( $p>0.05)$ (Table 5). These values were below the standards $(1.49 \mathrm{~kg})$ established by Hy-Line International (2005) for laying hens of the Hy-Line breed because of the temperatures during the course of the assay. However, they are within normal standards compared to tables from National Research Council (NRC, 1994). There were no differences in feed conversion among treatments $(p>0.05)$, except for birds with $20 \%$ inclusion, which differentiated from controls $(p \leq 0.05)$ due to a high intake and lower production presented compared to the other treatments. Lumpkins et al. (2005) also observed a trend towards an increase in feed conversion with respect to controls by incorporating $15 \%$ corn DDGS in the diet, which is in agreement with the results of this study. The results for feed conversion obtained in the current study are analyzed and are within normal standards compared with tables from the NRC (1994).

\section{Mortality}

No cases of mortality were observed.

\section{Egg weight}

In Table 5, it can be observed that there was a slight variation in recorded values between 62.8 $\mathrm{g}$ in birds from the $10 \%$ inclusion treatment group and $65.2 \mathrm{~g}$ for birds from the $15 \%$ inclusion treatment group. In this case, significant differences were found $(p \leq 0.05)$ between birds from treatments 10 and $15 \%$ and between 0 and $20 \%$, but a consistent trend was not observed in changes in egg weight with increasing DDGS inclusion levels. Three out of four treatments 
where in DDGS was included in the diet led to a slight decrease in weight with respect to control birds. Nevertheless, the egg weight of $65.2 \mathrm{~g}$ of birds in the treatment group with $15 \%$ inclusion was still slightly higher than birds from the control group and only significantly differentiated from birds in the 10 and $20 \%$ treatment groups. The results are similar to those obtained by Roberson et al. (2005), who found a decrease in the egg weight by including up to $10 \%$ DDGS in diet, but by including $15 \%$ corn DDGS as a replacement for soybean concentrate, they also observed a rise in the egg weight. According to Lumpkins et al. (2005), who assessed behavior in laying hens after including up to $15 \%$ corn DDGS in the diet, no significant differences were observed in the weights of the eggs. The main measured factors related to egg weight are follows: energy, proteins, methionine and lysine (Castello et al., 1989; Leeson et al., 2000). By analyzing the nutrients provided by the ingredients of the diet (Table 2), as well as the nutritional analyses of the diet, no nutritional deficiency was observed. Therefore, the observed slight decrease in the egg weight could be attributed to other factors, such as the protein quality of the DDGS (Lumpkins et al., 2005) and the availability and digestibility of the amino acids found below the corn grain (Batal and Dale, 2006) as a result of the application of high temperatures during the process of bioethanol production. Temperatures oscillated between 130 and $620{ }^{\circ} \mathrm{C}$ (U.S. Grain Council, 2012). Among the main factors that influence the digestibility of the protein, the nature of the protein is highlighted. Treatments by heat, pressure or steam or the nature of the remaining elements of the diet should be mentioned (De Blas and Gonzalez, 1991). In the nutritional analysis during the study, an increase in the raw fiber was observed as DDGS levels increased in the diet. De Blas and Gonzalez (1991) indicate that a high content of raw fiber in the diet results in the greater secretion of mucin in the intestine, and endogenous losses of amino acids increase.

\section{Egg mass}

This parameter indicates the total mass of the eggs produced by a hen as a daily average and directly depends on the number of eggs produced and their weight. Significant differences were found $(\mathrm{p} \leq 0.05)$ among the control treatment $(60.57$ g) and the birds from treatments 5, 10, 15 and 20\% (with values of 58.00, 57.72, 57.6 and $56.34 \mathrm{~g}$, respectively), which indicates that the egg masses in all treatment groups were lower than the control treatment (Table 5). Among birds from the 5, 15 and $20 \%$ treatment groups, the egg mass was not affected ( $\mathrm{p}>0.05$ ); although between birds from treatment groups with 15 and $20 \%$ inclusion, a notable decrease was observed, with a difference of $1.4 \mathrm{~g}$. As egg mass depends on both production and egg weight, this parameter followed the same production trend, which was affected by high temperatures.

\section{Yolk color}

An increment in yolk color was produced as the DDGS percentage was increased in the diet. Significant differences were observed $(\mathrm{p} \leq 0.05)$ among birds from the control group and birds from the other treatments (Table 5). However, the variation range in the Hoffmann - La Roche scale was minimal, ranging from 10 for control birds to 11 for birds from the treatment group with 20\% DDGS inclusion. This trend was also observed by Roberson et al. (2005). In contrast, Lumpkins et al. (2005) found no significant differences ( $p>0.05$ ) by including 15\% corn DDGS in the diet. Yolk color depends exclusively on the feed consumed by the hen, particularly on the total level of xanthophylls contained in the diet (Castello et al., 1989). Xanthophylls are generally supplied by natural raw materials such as corn (De Blas and Gonzalez, 1991). Leeson et al. (2000) found that higher levels of corn in the diet have a positive effect on yolk color. Therefore, we can deduce that DDGS corn retains most of 
the xanthophylls and higher amounts in the diet may cause greater color intensity of the yolk.

\section{Shell thickness}

Variation in the egg shell thickness among different treatments was $33-34 \mathrm{~mm}$, and statistically there were no differences $(\mathrm{p}>0.05)$ from control (Table 5). Calcium content in the diet is the most important nutritional factor in relation to the quality of the egg shell because $90 \%$ of the minerals are contained in the shell, and 98\% correspond to calcium (De Blas and Gonzalez, 1991). DDGS contains $0.22 \%$ calcium, a value that is below soybean concentrate (0.67\%) but above corn (0.03\%) (Cuca et al., 2003). Because soybean concentrate was replaced by DDGS, the calcium percentage provided in the diet (Table 3) decreased 0.06 percentage points. However, no limitations were observed with respect to the formation of the egg shell by using up to $20 \%$ corn DDGS in the diet of laying hens. Therefore, this production parameter was not affected by the inclusion of DDGS in soybean bran replacement. However, a slight decrease in the weight and mass variables, but not pigmentation, was observed for egg quality. Based on these considerations, we conclude that DDGS can replace soybean bran in the diet of laying hens in levels up to $20 \%$ of the total feed without affecting production, and these conclusions are due to the lack of significant differences between treatments for important egg laying parameters.

\section{Acknowledgments}

Proyect VRID. Iniciación 213.121.015-1.0: “Uso de nutrachic proteina ( $r$ ) en reemplazo de soya en raciones para pollos de carne". Financing: Vicerrectoría de Investigación y Desarrollo of Universidad de Concepción. Chile.

\section{Resumen}

H.E. Rodríguez-Ríos, J.A. Campos-Parra, P.A. Williams-Salinas, M.H. Blanck-Heimann, R.G. Astudillo-Neira y J.D. Grande-Cano. 2015. Inclusión de granos secos de destilería con solubles en gallinas de postura en la alimentación durante la etapa de postura. Cien. Inv. Agr. 42(3): 331-339. El objetivo de este ensayo fue evaluar el uso de granos secos de destilería con solubles (DDGS) en la dieta de gallinas de postura en relación a los parámetros productivos (peso vivo, porcentaje de postura, consumo de alimento) y calidad del huevo (peso de huevo, masa, color de yema y grosor de la cáscara). Este estudio fue realizado en la Cordillera de los Andes, Comuna de Parral, Chile. Tuvo una duración de 13 semanas de postura, desde la semana 31 a la 44 de vida de las aves. El diseño experimental fue bloques completos al azar, usando 225 gallinas de la raza Hy-Line Brown, distribuidas en 5 tratamientos, donde cada uno tuvo 15 repeticiones de 15 gallinas. El tratamiento consistió en el reemplazo en diferentes niveles del concentrado de soya por DDGS, que correspondieron a niveles de inclusión en la dieta de 5, 10, 15 y 20\%. El color de la yema fue mayor con aportes incrementales de DDGS. Se concluye que el uso de DDGS es posible como reemplazo del afrecho de soya en niveles de hasta $20 \%$ en la dieta de gallinas de postura, debido a la falta de diferencias estadísticas entre tratamientos postura de huevos.

Palabras clave: Afrecho de soya, Hy-line Brown, producción de huevos. 


\section{References}

Balzarini, M.G., L. González, M. Tablada, F. Casanoves, J.A. Di Rienzo, and C.W. Robledo. 2008. InfoStat: software estadístico: manual del usuario. Versión 2008. Brujas. Córdoba, Argentina.

Batal, B., and N. Dale. 2006. True metabolizable energy and aminoacid digestibility of distiller's diet grains with solubles. J. Appl. Poult. Res. 15: 89-93.

Calvert, J. 1978. Climatización de gallineros. Sanz B. (tr.). 1era edición. Acribia. Zaragoza, España. 89 pp.

Castello, J., F. Franco, and M. Pontes. 1989. Producción de huevos. Real Escuela de Avicultura. Barcelona, España. 367 pp.

Conover, W.J. 1999. Practical Nonparametric Statistics. John Wiley \& Sons, Inc., New York. 584 pp.

Cuca, M., E. Avila, A. Pro, H. Rodríguez, and S. Donoso. 2003. Alimentación de las aves. Universidad de Concepción. Chillán, Chile, 124 pp.

Cunniff, P. 1996. Official methods of analysis of AOAC International. 16th ed. AOAC International. Gaithersburg, U.S.A. 1230 pp.

De Blas, C. de and G. González. 1991. Nutrición y alimentación de gallinas ponedoras. Ediciones Mundi-Prensa. Madrid, España, 263 pp.

De Camargo Bini, D., Lenis, M., M. De Almeida Prado Sampaio, and M. Ullivarri. 2011. Indústria sucro-alcooleira na Argentina, no Brasil e o contexto dos bio-combustíveis no continente americano. Revista Geográfica de América Central, Numero Especial EGAL, 2011-Cota Rica. II Smenestre 2011. 16 pp. Available online at: <http://revistas. una.ac.cr/ index.php/geografica/article/view/2391 (Website accessed: Jan 16. 2013).

Duncan, A.J. 1974. Quality Control and Industrial Statistics. 4th Ed., Ed. Irwin, Homewoods, III. Elwinger, K. 2007. Feedstuffs and diets for laying hens and slaughter chickens. Dept. of Animal Nutrition and Management. Available online at: http://webcache.gleusercontent.com/search?q=ca che:k3OUpKe0QH4J:poultry.huv.slu.se/hen/FEE DSTUFFS\%2520AND\%2520DIETS1001.doc +f eedstuffs+and+diets + for+laying + hens + and + slau ghter + chickens + Klas + Elwinger $\& \mathrm{~cd}=2 \& \mathrm{hl}=$ es \&c $\mathrm{t}=\mathrm{clnk} \& \mathrm{gl}=\mathrm{cl}$ (Website accessed: July 25, 2010).
Elwinger, K. 2007. Feedstuffs and diets for laying hens and slaughter chickens. Dept. of Animal Nutrition and Management. Available online at: http://webcache.gleusercontent.com/search? $\mathrm{q}=$ cache: $\mathrm{k} 3 \mathrm{O}$ UpKe0QH4J:poultry.huv.slu.se/hen/FEEDSTUF FS\%2520AND\%2520DIETS1001.doc+feedstuf fs+and+diets+for+laying+hens+and+slaughter+ chickens + Klas + Elwinger $\& \mathrm{~cd}=2 \& \mathrm{hl}=\mathrm{es} \& \mathrm{ct}=\mathrm{cln}$ $\mathrm{k} \& \mathrm{gl}=\mathrm{cl}$ (Website accessed: July 25, 2010).

Fundación Chile. 2007. Análisis y evaluación de la competitividad y transparencia del mercado nacional del maíz: informe final. ODEPA. Available online at: http://www.indap.gob.cl/component/ option,com_remository/Itemid,114/func,fileinfo/ id, 1624/ (Website accessed: May 4, 2010).

Gibson, M. and K. Karges. 2006. DDG/S Production: Present and Future. Dakota Gold Research Association. Available online at: http://www. poetenergy.com/ files/division_files/DDGS $\% 20$ Production\%20-\%20ML\%20Gibson\%20-\%20 090706\%20FINAL.pdf (Website accessed: July 18, 2010).

Hy-Line International. 2005. Hy-Line variedad brown. Guía de manejo comercial. Hy-Line International. West Des Moins. Iowa, U.S.A., 23 pp.

Leeson, S., J. Summers, and G. Diaz. 2000. Nutrición aviar comercial. Le'Print Clubb Express Ltda. Santafé de Bogotá, Colombia. 123 pp.

Lumpkins, B., A. Batal, and N. Dale. 2005. Use of distillers dried grains plus solubles in laying hen diets. J. Appl. Poult. Res. 14: 25-31.

Olsson N. 1936. International Review of Poultry Science. Official Organ of the World's Poultry Science Association. Ed. Dr. B. J. C. TE Hennepe. Published by Fritz Pfenningstorff, Berlin.310 pp.

Muñoz-Lagos, Roberto E., Ortega-Blu, Rodrigo A., Acosta-Espejo, Luis G., and R.A. González-Platteau. 2010. Biocombustibles en Chile. II. Evaluación económica de la elaboración de biocombustibles. Agrociencia 44:849-859.

NRC-National Research Council. 1994. Nutrient requirements of chickens. p. 19-34. In: Nutrient requierement of Poultry. 9th. ed. National Academy Press. Washington, D.C., U.S.A.

ODEPA-Oficina de Estudios y Políticas Agrarias. 2010. In: G. Covacevic and V. Esnaola (eds). 
Producción de Huevos. Santiago, Chile. Boletín Mercados Agropecuarios Nº 219.

Roberson, K., J. Kalbfleisch, W. Pan, and R. Charbeneau. 2005. Effect of corn distiller's dried grains with solubles at various levels on performance of laying hens and egg yolk color. Int. J. Poult. Sci. 4: 44-51.

U.S. Grain Council. 2012. A GUIDE TO Distiller's
Dried Grains with Solubles (DDGS). Third Edition. Available online at: http://www.grains.org/ sites/default/files/ddgs-andbook/Complete $\% 20$ 2012\%20DDGS\%20Handbook.pdf.

Waldroup, P., Z. Wang, C. Coto, S. Cerrate, and F. Yan. 2007. Development of a standardized nutrient matrix for corn distillers dried grains with solubles. Int. J. Poult. Sci. 6: 478-483. 